\title{
A New Filamentous, Gliding Bacterium, Filibacter limicola gen. nov. sp. nov., from Lake Sediment
}

\author{
By MARK F. J. MAIDEN* AND J. GWYNFRYN JONES \\ Freshwater Biological Association, Windermere Laboratory. The Ferry House, Ambleside, \\ Cumbria LA22 OLP, UK
}

(Received 24 May 1984; revised 18 June 1984)

\begin{abstract}
A new, Gram-negative, multicellular, filamentous, gliding bacterium is described. The organism was isolated from the sediment of a eutrophic lake on a dilute peptone medium. The growth habit on solid media was characterized by spreading whorls of growth and spiral colonies. Filaments, 8 to $150 \mu \mathrm{m}$ long, were composed of cylindrical cells $1.1 \mu \mathrm{m}$ wide by 3 to $30 \mu \mathrm{m}$ long. Junctions between individual cells within a filament were marked by constrictions. The organism was not pigmented, and therefore resembled members of the genus Vitreoscilla. Comparision with two Vitreoscilla strains showed important differences in cytochrome composition, DNA base composition, isoprenoid quinone content, and sensitivity to actinomycin D, which indicated that the isolate was more closely related to the Flexibacteriaceae than to Vitreoscilla spp. The organism did not resemble any previously described taxon of Flexibacteriaceae. On the basis of differences from both Vitreoscilla spp. and flexibacteria it is proposed that the organism be placed in a new genus, Filibacter, with the type species named as Filibacter limicola sp. nov., from its origin in sediment. The type strain of $F$. limicola is $1 \mathrm{SS} 101$ (NCIB 11923).

The organism was a strict aerobe capable of growth on defined mixtures of amino acids, and had a requirement for vitamins. Only amino acids served as substrates. The organism required particular combinations of amino acids for growth. No single amino acid or mixture of amino acids from a single biosynthetic family supported growth.
\end{abstract}

\section{INTRODUCTION}

A wide variety of filamentous bacteria are found in freshwater sediments. Being large and distinctive in morphology, they are readily observed and recognized in material from these environments. However, only recently has a methodical ecological survey of the qualitative and quantitative distribution of filamentous bacteria in relation to environmental factors been made (Godinho-Orlandi \& Jones, $1981 a, b$ ). Also, only a few of these organisms have been isolated and studied, and many are known only by morphological descriptions. Thus, although it is now recognized that filamentous organisms are much more important in terms of biomass than is indicated by their low numbers (Jergensen, 1977; Godinho-Orlandi \& Jones, $1981 a$ ), very little is known of their physiological activities and contributions to nutrient cycling processes in sediments. One notable exception to this is Beggiatoa. Populations of this organism have been shown to have the potential to oxidize all the sulphides produced in the marine sediments in which they occur (Jorgensen, 1977).

Common among the filamentous bacteria observed in sediment are multicellular gliding organisms which resemble the genus Vitreoscilla. Pringsheim $(1949,1951)$ proposed the family Vitreoscillaceae for a group of colourless, multicellular, gliding filamentous bacteria. The genus Vitreoscilla was described, with a number of species isolated from dung and ditch mud, and differentiated by morphological features. Only one of these species, $V$. stercoraria, is still available for study (strain ATCC 15218). The only other cultures of Vitreoscilla spp. available 
are two strains of Costerton et al. (1961) (strains ATCC 13981 and 13982). There has been no study of the genus Vitreoscilla since that of Pringsheim (1951), and therefore the taxonomic standing of the species described, and the relationship of the genus to other filamentous bacteria, are uncertain. The other genus of the Vitreoscillaceae of Pringsheim (1951), Microscilla, is now considered to be a member of the Cytophaga/Flexibacter group (Lewin, 1969). The only recently published work on vitreoscillas has dealt with the ultrastructure of two strains (Costerton et al., 1961), the physiology of one named strain ( $V$. stercoraria; Mayfield \& Kester, 1972,1975 ), and the cytochrome system of one strain (Webster \& Hackett, 1966a, b). The occurrence of plasmid DNA in some of these organisms has been reported recently by Minges $e$ t al. (1983). A recent review of the Beggiatoaceae (Wiessner, 1981) mentioned Vitreoscilla only briefly, reflecting the complete lack of taxonomic information on the genus. In contrast, members of the family Flexibacteriaceae, encompassing the major genera Cytophaga and Flexibacter, have been well studied (Lewin \& Lounsbery, 1969; Soriano, 1973; Christensen, 1977; Reichenbach \& Dworkin, 1981). These organisms are also found in lake sediments, and are characterized by unicellular filaments which flex actively. Macroscopic growth is brightly coloured due to the presence of carotenoid and flexirubin-type pigments.

Filamentous bacteria as a group encompass organisms with a variety of physiologies. Most are heterotrophic, utilizing a wide range of organic substrates. Leptothrix and Sphaerotilus species can use a large number of simple compounds as carbon and energy sources (van Veen $e t$ al., 1978), whereas Cytophaga spp. are able to degrade polymeric substrates such as cellulose or chitin. Beggiatoa utilizes acetate and a small number of other simple compounds (Pringsheim, 1964; Nelson \& Castenholz, 1981), and although it is not autotrophic as originally thought, some strains may be mixotrophic (Güde et al., 1981), obtaining some of their energy from the oxidation of sulphides. There is evidence that some strains can assimilate carbon dioxide (Strohl et al., 1979, 1981). Apart from Beggiatoa and the filamentous cyanobacteria, there is no evidence for autotrophy or mixotrophy in other filamentous bacteria. Most are strict aerobes with respiratory metabolisms, but some are facultative anaerobes with fermentative and respiratory metabolisms. Desulfonema (Pfennig et al., 1981) is an anaerobic, sulphate-reducing, gliding filamentous bacterium. It has been reported to use acetate, higher fatty acids, succinate or fumarate as electron donors and carbon sources (Widdel et al., 1983). Capnocytophaga species are strict anaerobes with solely fermentative metabolisms (Reichenbach \& Dworkin, 1981).

Some filamentous bacteria may be specialized in the utilization of a small range of substrates. Examples are Microthrix parvicella which utilizes only certain fatty acids (Slijkhuis \& Deinema, 1982), and Vitreoscilla stercoraria which Mayfield \& Kester $(1972,1975)$ reported could use only certain mixtures of amino acids as carbon and energy sources.

A study of filamentous bacteria in sediments (Maiden, 1983) resulted in the isolation of the organism (isolate ISS101) described in this paper. It resembled members of the genus Vitreoscilla and was compared with two available strains of Vitreoscilla spp. The physiology of the isolate was studied, particularly its carbon metabolism.

\section{METHODS}

Source and treatment of sediment. Sediment from Blelham Tarn, the lake in the English Lake District where the greatest numbers and variety of filamentous bacteria had been observed (Godinho-Orlandi \& Jones, 1981 a), was sampled using a Jenkin surface-mud sampier (Ohnstad \& Joncs, 1982). Profundal (deep water) cores were taken at 13-14 m depth, and the top 1-2 cm layer of sediment was extruded and removed (Ohnstad \& Jones, 1982). This sediment was diluted as required in filtered lake water, mixed vigorously with a vortex mixer, and used for the inoculation of isolation media. All inocula were checked microscopically for the presence of filamentous bacteria.

Microscopy. Routine microscopy of sediment and cultures was done on a Leitz Dialux microscope fitted with the interference contrast device $T$.

Media. TSB was Tryptone soya broth (Oxoid CM129), TSA was Tryptone soya agar (Oxoid CM131), NB was Nutrient broth (Oxoid CMI), and NA was Nutrient agar (Oxoid CM3). Isolation media were based on mineral base $M$ which was the Artificial Esthwaite medium of Jones (1983). The composition was (mg $\left.\mathbf{I}^{-1}\right): \mathrm{K}_{2} \mathrm{HPO}_{4}, 28$; $\mathrm{MgCl}_{2} .6 \mathrm{H}_{2} \mathrm{O}, 127 ; \mathrm{KNO}_{3}, 4 ;\left(\mathrm{NH}_{4}\right)_{2} \mathrm{SO}_{4}, 60 ; \mathrm{MnSO}_{4}, 4 \mathrm{H}_{2} \mathrm{O}, 8$; ferric citrate, 6. The $\mathrm{pH}$ of the medium was adjusted with $1 \mathrm{M}-\mathrm{KHCO}_{3}$ before autoclaving, and the final $\mathrm{pH}$ was 7.0-7.2. The media contained yeast extract (YE; Difco, $10 \mathrm{mg}^{-1}$ ) and peptone (Oxoid L37, $100 \mathrm{mg}^{-1}$ ) as follows: MY medium, YE only; MP medium, 
peptone only; MYP medium, YE plus peptone. For plates, the media were solidified with $1 \%(w / v)$ agar (Oxoid L28).

For defined media, the mineral base used was a modification of the medium $L$ of Leadbetter \& Foster (1958). Modified medium $\mathrm{L}$ (ML medium) had no $\mathrm{NaH}_{2} \mathrm{PO}_{4}$, an increased concentration of $\mathrm{Na}_{2} \mathrm{HPO}_{4}$ and $\mathrm{NaNO}_{3}$ replaced with $\mathrm{NH}_{4} \mathrm{NO}_{3}$. The composition was as follows $\left(\mathrm{mg} \mathrm{l}^{-1}\right): \mathrm{Na}_{2} \mathrm{HPO}_{4}, 767 ; \mathrm{MgSO}_{4} .7 \mathrm{H}_{2} \mathrm{O}, 200 ; \mathrm{KCl}, 40$; $\mathrm{CaCl}_{2} .2 \mathrm{H}_{2} \mathrm{O}, 15 ; \mathrm{NH}_{4} \mathrm{NO}_{3}, 2000 ; \mathrm{FeSO}_{4} .7 \mathrm{H}_{2} \mathrm{O}, 1 ; \mathrm{MnSO}_{4}, 4 \mathrm{H}_{2} \mathrm{O}, 0 \cdot 1$. For trace metals the solution of Patel et al. (1978) was used. The medium was sterilized by autoclaving at $121^{\circ} \mathrm{C}$ for $15 \mathrm{~min}$. After autoclaving, ML medium was slightly cloudy but cleared on cooling. The final $\mathrm{pH}$ was 7.4. The vitamin solution used was that of Wolin et al. (1963). The 19 amino acids were grouped in families based on common biosynthetic pathways (Dawes \& Large, 1973) as follows. Glutamate family, glutamate, glutamine, arginine and proline; aspartate family, aspartate. asparagine, lysine, threonine, isoleucine and methionine; aromatic family, tryptophan, phenylalanine and tyrosine; serine family, serine, glycine and cysteine; pyruvate family, alanine, valine and leucine. Histidine, citrulline and ornithine were also used individually. All (except glycine) were L-amino acids (Sigma). Each amino acid was provided at a final concentration of $2 \mathrm{mg}$ atom amino acid carbon $\mathrm{l}^{-1}$, except tyrosine $\left(0.5 \mathrm{mg} \mathrm{atom}^{-1}\right)$. The complete amino acid mixture contained the 19 amino acids of the five families.

Incubation. Unless otherwise stated, all incubations were at $20^{\circ} \mathrm{C}$, shaken when required in an orbital incubator at 120 r.p.m.

Isolation and purification of cultures. Sediment samples $(10 \mu \mathrm{l})$ were streaked on the various isolation media and incubated at $10^{\circ} \mathrm{C}$ and $20^{\circ} \mathrm{C}$. Plates were examined by eye, and through a $32 \times$ long working distance objective. Any filaments developing away from contaminants were subcultured by excizing the surrounding agar as a block, and transferring this to a plate of fresh medium. This was repeated until pure cultures were obtained. Purity was checked on TSA and NA plates, and the cultures were maintained on TSA slopes incubated at $20^{\circ} \mathrm{C}$, and stored at $10^{\circ} \mathrm{C}$.

Culture of Vitreoscilla strains. The Virreoscilla strains for taxonomic comparison were Vitreoscilla stercoraria (ATCC 15218) and Vitreoscilla sp. strain 390 (Costerton et al., 1961). Cultures were maintained on TSA slopes.

Preparation of standard inocula. Exponential phase cultures were prepared from $24 \mathrm{~h}, 20^{\circ} \mathrm{C}$ static broth cultures, and incubated for $20-24 \mathrm{~h}$ at $20^{\circ} \mathrm{C}$ in an orbital incubator (120 r.p.m.). Defined media and commercial test systems were inoculated with washed cell suspensions. The cells were harvested by centrifugation $(1800 \mathrm{~g}, 10 \mathrm{~min})$, washed twice, and resuspended in sterile mineral medium or buffer.

Antibioric sensitivity. Samples $(0.1 \mathrm{ml})$ of a $24 \mathrm{~h}$ broth culture of the test organism were spread on TSA and NA plates. The antibiotics and inhibitori, and the quantity per disc $(\mu \mathrm{g})$, used were; chloramphenicol, tetracycline, streptomycin, kanamycin, neomycin, cycloheximide and penicillin $G(0 \cdot 1,1,10,100,1000) ; 2,4-$ dinitrophenol and rotenone $(0 \cdot 1,1,10,100)$; and actinomycin $\mathrm{D}(1,10,40)$. The plates were examined after incubation at $20^{\circ} \mathrm{C}$ for $2 \mathrm{~d}$ and zones of inhibition recorded.

Morphology and cytology. Agar-coated slide mounts were used to examine the gross morphology of filaments and cells. A drop of cell suspension ( $15 \mu \mathrm{l})$ was added to agar $(25 \mu \mathrm{l} ; 1 \%, \mathrm{w} / \mathrm{v})$ spread evenly on a clean glass slide, and sealed under a coverslip with Vaseline. Cells and filaments of the isolated strain were also examined by transmission electron microscopy. Drops of a $24 \mathrm{~h}$ broth culture were placed onto carbon stabilized Formvar films on 300 mesh copper grids. After 1 h excess liquid was removed and the specimen shadowed with gold/palladium. The electron microscope used was a Corinth 500 (AEI) and the grids were examined with an accelerating voitage of $60 \mathrm{kV}$. Electron micrographs were taken using Agva F071P Rapidoline Ortho film, with an exposure time of $2 \mathrm{~s}$. The colonial morphology/growth habits of strains on solid media were observed, and wet mounts were examined for evidence of motility. The sodium chloride/Tylers crystal violet method (Conn \& Jennison, 1957) and negative stains using nigrosin $(1 \%, w / v)$ or drawing ink were used to detect sheaths. Negative stains, the Alcian Blue stain and Hiss's capsule stain (Doetsch, 1981) were used to detect capsules or slime. To detect flagella the stains of Leifson (1951) and Mayfield \& Inniss (1977) were used. All other stains used were as described by Norris \& Swain (1971) and Doetsch (1981).

Cyrochrome spectrophotometry. For each strain, $2 \times 250 \mathrm{ml}$ TSB cultures in 1 litre Erlenmeyer fiasks were grown at $20^{\circ} \mathrm{C}$, shaken, for $60 \mathrm{~h}$. The cells were harvested $\left(1600 \mathrm{~g}, 10^{\circ} \mathrm{C}\right)$, washed twice in $0.1 \mathrm{M}$-phosphate buffer, pH 7.4, and resuspended in buffer. Samples $(10 \mathrm{ml})$ were sonicated with an exponential probe (tip amplitude $84 \mu \mathrm{m})$ for a total of $5 \mathrm{~min}$ in $30 \mathrm{~s}$ bursts with $15 \mathrm{~s}$ rest periods. Sonicate $(0.6 \mathrm{ml})$ was further clarified by mixing with sodium deoxycholate $(0.03 \mathrm{~g}$ in $2.4 \mathrm{ml}$ phosphate buffer). The samples were then placed in an LR ultrasonic bath for $3 \mathrm{~min}$ and remixed. Treated sonicates were diluted $10^{-1}$ and spectra were recorded using a Pye-Unicam SP8-100 UV spectrophotometer. Absolute spectra were recorded with potassium ferricyanide $\left(30 \mathrm{mmol} 1^{-1}\right)$ as oxidizing agent and sodium dithionite $\left(200 \mathrm{mmol} \mathrm{l}^{-1}\right)$ as reducing agent. Dithionite-reduced minus ferricyanideoxidized difference spectra were also recorded.

Isoprenoid quinones. Freeze-dried samples of isolate $1 \mathrm{SS101}$ and Vitreoscilla stercoraria were analysed for major isoprenologs as described by Collins \& Jones (1981)

Determination of $T_{m}$ of DNA. Harvested cells were washed twice in saline/EDTA $(0.15 \mathrm{M}-\mathrm{NaCl}, 0.1 \mathrm{M}-\mathrm{EDTA}$, pH 8.0). For extraction of DNA, 2-3 g (wet weight) of cell slurries were treated by the method of Marmur (1961), 
as far as the first precipitation. The DNA was purified by the method of Gibson \& Ogden (1979), using column chromatography with Sepharose 4B. The spectra $(230-300 \mathrm{~nm})$ of the purified DNAs were measured to check their purity. The melting temperature $\left(T_{m}\right)$ of each purified DNA sample was determined using a UV-visible microprocessor controlled Spectrophotometer System 2600 with temperature programmer (Gilford Instruments Laboratories Inc., Corning Glass Works, Corning, NY, USA).

Physiology. The oxygen requirements of the strains were determined using streak plates incubated in air, at low oxygen tension, and anaerobically (BBL Gas Pak system, $\mathrm{H}_{2}+\mathrm{CO}_{2}$ ). Agar shake cultures in solid and semi-solid agar deeps (TSB + agar at $0.2,0.5$ and $1.0 \%, w / v$ ) were also used. Some tubes of each agar concentration were sealed with plugs of $1 \%(w / v)$ agar. Optimum growth temperatures were determined from the growth curves of cultures (25 ml TSB in $250 \mathrm{ml}$ Erlenmeyer flasks) incubated at $4,10,15,20,25,30,35$ and $40^{\circ} \mathrm{C}$. Casein hydrolysis was tested on TSA plus $1 \%(\mathrm{w} / \mathrm{v})$ casein. The plates were developed by flooding with $0.1 \mathrm{M}-\mathrm{HCl}$. Gelatin hydrolysis was tested on TSB solidified with agar (Oxoid L28, 0.5\%, w/v) plus gelatin (Oxoid L8, 0.5\%, w/v), and developed with tannic acid $(1 \%, \mathrm{w} / \mathrm{v})$. Starch hydrolysis was tested on TSA plus $0.2 \%(\mathrm{w} / \mathrm{v})$ starch, and developed with Gram's iodine. Growth on amino acids only was tested on ML medium plus the complete amino acid mixture and vitamins. Details of tests for the utilization of various carbon sources and amino acid combinations by the isolated strain are given below. Strains were tested for catalase, and for oxidase reaction by the method of Kovacs (1956). A range of biochemical tests were performed using the API 20B commercial identification system. Strips were inoculated with washed cell suspensions, and incubated at $20^{\circ} \mathrm{C}$ for $3 \mathrm{~d}$. The organisms were also tested by the API ZYM system which provided assays for 19 enzymes. Test strips were inoculated with dense washed cell suspensions, and incubated at $25^{\circ} \mathrm{C}$ for $\mathrm{Sh}$. The strains were tested for the oxidation of sulphide and the deposition of intracellular sulphur granules. Sodium sulphide solution $(10 \mu \mathrm{l}$, approximately $125 \mathrm{~mm})$ plus cell suspension $(10 \mu l)$ were mixed on a glass slide, and sealed under a coverslip with Vaseline. Cells were examined for the presence of intracellular sulphur granules immediately and after $0.5 \mathrm{~h}$. Cultures in TSB $(5 \mathrm{ml}$ plus $0.1 \mathrm{ml}$ sulphide solution as above) were also examined for sulphur granules after incubation at $20^{\circ} \mathrm{C}$ for $2 \mathrm{~d}$.

Measurement of optical density and dry weight. The OD of cultures was measured at $540 \mathrm{~nm}$ with a Cecil CE 292 spectrophotometer (Cambridge, UK). When necessary, samples were diluted to give an OD of less than 0.4. OD was calibrated against dry weight $\left(80^{\circ} \mathrm{C}, 24 \mathrm{~h}\right)$.

Nephelometry. Cell densities in test-tube cultures were determined using an EEL nephelometer head and Unigalv galvanometer. This method was used to test the growth responses of isolate 1SS101 to single amino acids, mixtures of amino acids from a single family, and omissions of single families or pairs of families from the complete mixture. Some of the carbon sources (without amino acids added) were also screened by this method.

Growth yield experiments. These were used to determine the response to pairs and triplets of amino acid families, and to other carbon sources. Cultures were incubated, shaken, in $250 \mathrm{ml}$ Erlenmeyer flasks. Vitamins, amino acids and carbon sources were added as required to ML medium to a total volume of $75 \mathrm{ml}$. Positive controls contained the complete amino acid mixture, and negative controls contained ML medium plus vitamins, inoculated, but with no amino acids added. To test for the requirement for vitamins, a positive control without vitamin solution added was used.

The other potential carbon sources tested were: glucose, fructose, sucrose, lactose, galactose, mannitol, glucosamine, galacturonic acid, acetate, pyruvate, lactate, citrate, malate, glutamate, butyrate, ethanol, glycerol urea and bovine serum albumin (BSA), at concentrations equivalent to $20 \mathrm{mg}^{\mathrm{g}}$ atom carbon $\mathrm{1}^{-1}$ (organic acids added as sodium salts). All the compounds apart from sucrose, glutamate, urea and BSA were tested in the presence of the complete amino acid mixture at $2 \mathrm{mg}$ atom carbon $1^{-1}$ and $\mathbf{4 0} \mathrm{mg}$ atom carbon $1^{-1}$, with amino acids at $0.37 \mathrm{mg}$ atom carbon $\mathrm{I}^{-1}$ and $36.5 \mathrm{mg}$ atom carbon $1^{-1}$, and at $20 \mathrm{mg}$ atom carbon $\mathrm{l}^{-1}$, with amino acids at $3.65 \mathrm{mg}$ atom carbon $\mathrm{l}^{-1}$ and $18.25 \mathrm{mg}$ atom carbon $\mathrm{l}^{-1}$. The final $\mathrm{pH}$ of all cultures was measured. To enable direct comparison of the numerous amino acid family combinations, and of substrates with and without amino acids, single flasks were used for each combination. Positive controls were always in duplicate, and indicated good reproducibility between replicate flasks.

Auxamography. Plates of solidified ML plus vitamins medium, containing various combinations of amino acid families, were seeded with washed cell suspension, either by spreading, or in a semi-solid overlay. Crystals of individual amino acids were spotted onto the plates with sterile wooden applicator sticks. For testing each family, the basal media used contained complementary families which would support growth in combination with the added family (determined from results of amino acid family utilization experiments). For each plate, all the individual amino acids of the family being tested were applied in spot patterns designed to cater for multiple requirements or to show any synergistic effects.

\section{RESULTS}

Isolation

After $14 \mathrm{~d}$ incubation, microscopical examination of isolation plates showed the presence of filaments, singly and in small groups, often in circular formations, at some distance from the 
Table 1. Morphological and cytochemical data for isolate ISSI0I and the two Vitreoscilla strains

Characters in common: Gram-negative, non-branching, non-sheathed, non-pigmented, multicellular filaments with clearly constricted cell junctions.

\section{Morphological/cytochemical character}

Filament dimensions (width $\times$ length)

Cell dimensions (width $\times$ length)

Cell shape

Colonial morphology

Motility

Capsule

Slime

Endospores

PHB granules

Volutin granules

Isolate $1 S S 101$
$1 \cdot 1 \times 8-150 \mu \mathrm{m}$
$1 \cdot 1 \times 3-30 \mu \mathrm{m}$
ong rods, straight
or curved. rounded
ends
preading whoris and
spiral colonies
Gliding
+
+
+
-

V. stercoraria

$1.1-1.2 \times 10-200 \mu \mathrm{m}$

$1.1-1.2 \times 1.2-5 \mu \mathrm{m}$

Short rods, rounded ends

Vitreoscilla sp. strain 390

$1.1 \times 10-70 \mu \mathrm{m}$ $1.1 \times 1.1-3 \mu \mathrm{m}$

Short rods, rounded ends

Spreading whorls and Discrete, nonspiral colonies Gliding spreading colonies

-
+
+
-
$\overline{+}$
$\overline{+}$
\pm+

- Unstructured, extracellular material staining with carbol fuchsin. + Not all cells in smear contained stained inclusions.

streak lines. Such filaments were observed on plates of all three media and occurred most abundantly on MYP plates at $10^{\circ} \mathrm{C}$. Filaments were subcultured, and of the strains, all of which appeared identical, only one, coded $1 \mathrm{SS} 101$, was obtained in pure culture. The organism grew well on complex peptone-containing media such as NA and TSA.

\section{Characterization}

Isolate ISS101 was not sensitive to cycloheximide and rotenone, and was inhibited by the other agents, confirming its prokaryotic nature. It was much more sensitive to actinomycin D than were the Vitreoscilla strains.

The morphological and cytochemical characteristics of the three strains are given in Table 1. All three strains produced long filaments, those of 1SS101 being shorter than those of $V$. stercoraria (Fig. 1). In all cases the widths of cells were constant. The filaments of all the strains were multicellular, with the junctions between cells clearly marked by constriction. This was particularly so with the Vitreoscilla strains. With ISS101, the longer filaments were composed of longer cells, though in the longest cells, septa without corresponding constrictions could sometimes be seen. Cell length was not constant within single filaments. The cell lengths of the Vitreoscilla strains were one, two or at the most, three diameters. The growth habits on solid media of isolate $1 \mathrm{SS} 101$ and $V$. stercoraria were similar and very distinctive. Both spread widely over the surface of agar plates producing whorls of growth and spiral colonies (Fig. 2a, c). On some occasions, at $20^{\circ} \mathrm{C} 1 \mathrm{SS} 101$ grew predominantly as spiral colonies, as shown in Fig. $2(b)$. However, this behaviour was not consistent, and was probably due to the degree of dryness of the agar surface. Strain 390 formed discrete, non-spreading colonies. Cell masses of the three strains were not pigmented. Often cell aggregates of 1SS101, particularly the spiral colonies, were very refractile (Fig. $2 b$ ).

The distinctive growth habit of 1SS101, with cells spreading far from the point of inoculum, resembled that of $V$. stercoraria and suggested gliding motility. On observation of plates with a long working distance objective, some filaments could be seen to move slowly (up to $5 \mu \mathrm{m} \mathrm{min}^{-1}$ ). The non-spreading habit of Vitreoscilla strain 390 suggested that it was not actively motile. The culture was therefore considered to be aberrant as this strain should glide (Costerton et al., 1961). However, in all other morphological details, and biochemical tests, it was virtually identical to $V$. stercoraria and can therefore be considered a genuine Vitreoscilla strain. In wet mounts, 1 SS101 was usually immotile, but cells often showed small vibrating 

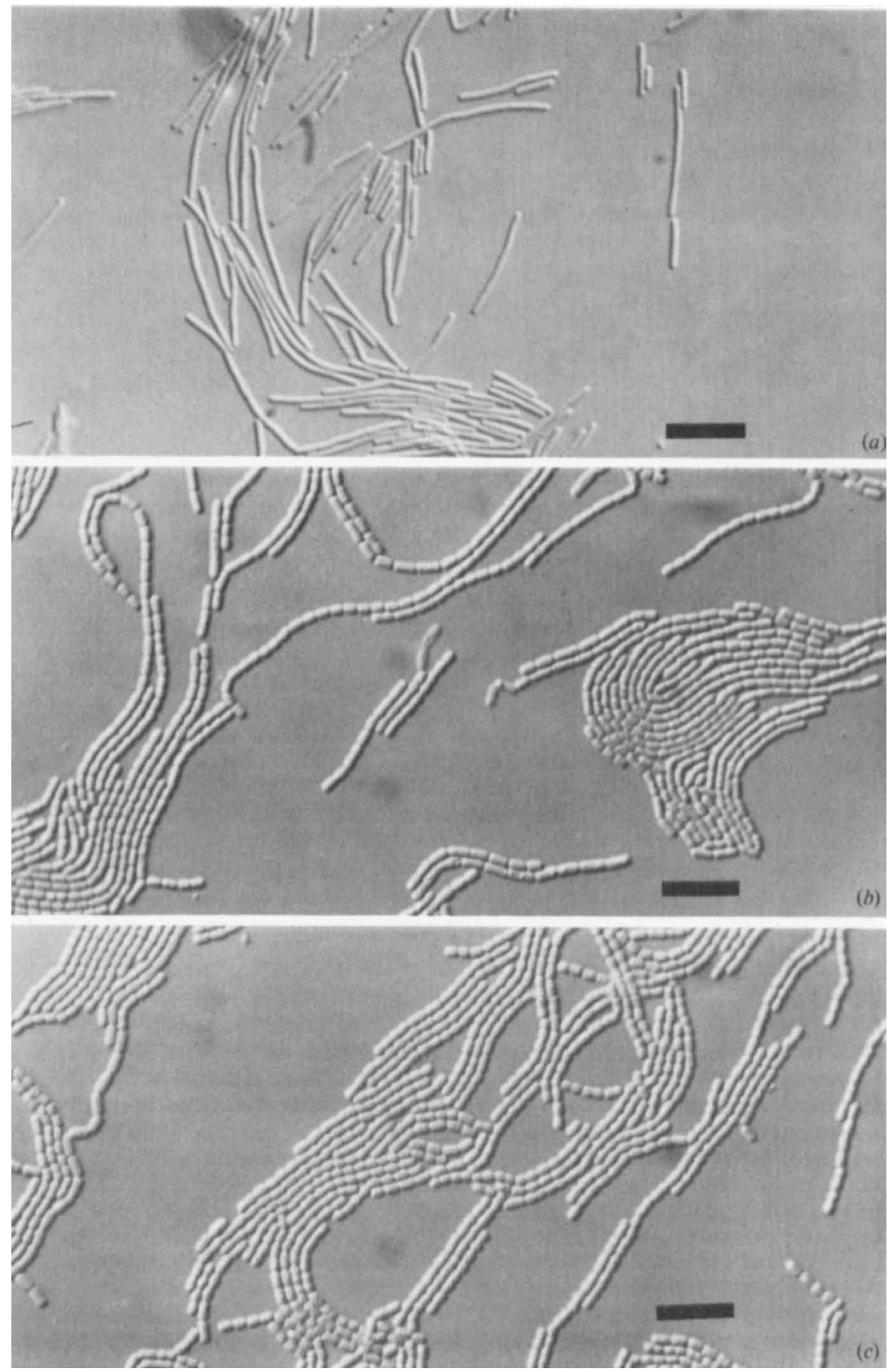

Fig. 1. Comparison of gross morphologies of isolate ISSI01 and the two Vilreoscilla strains. (a) Isolate ISS101, (b) V. stercoraria, (c) Vitreoscilla sp. strain 390. Agar-coated slide mounts; bars, $10 \mu \mathrm{m}$. 

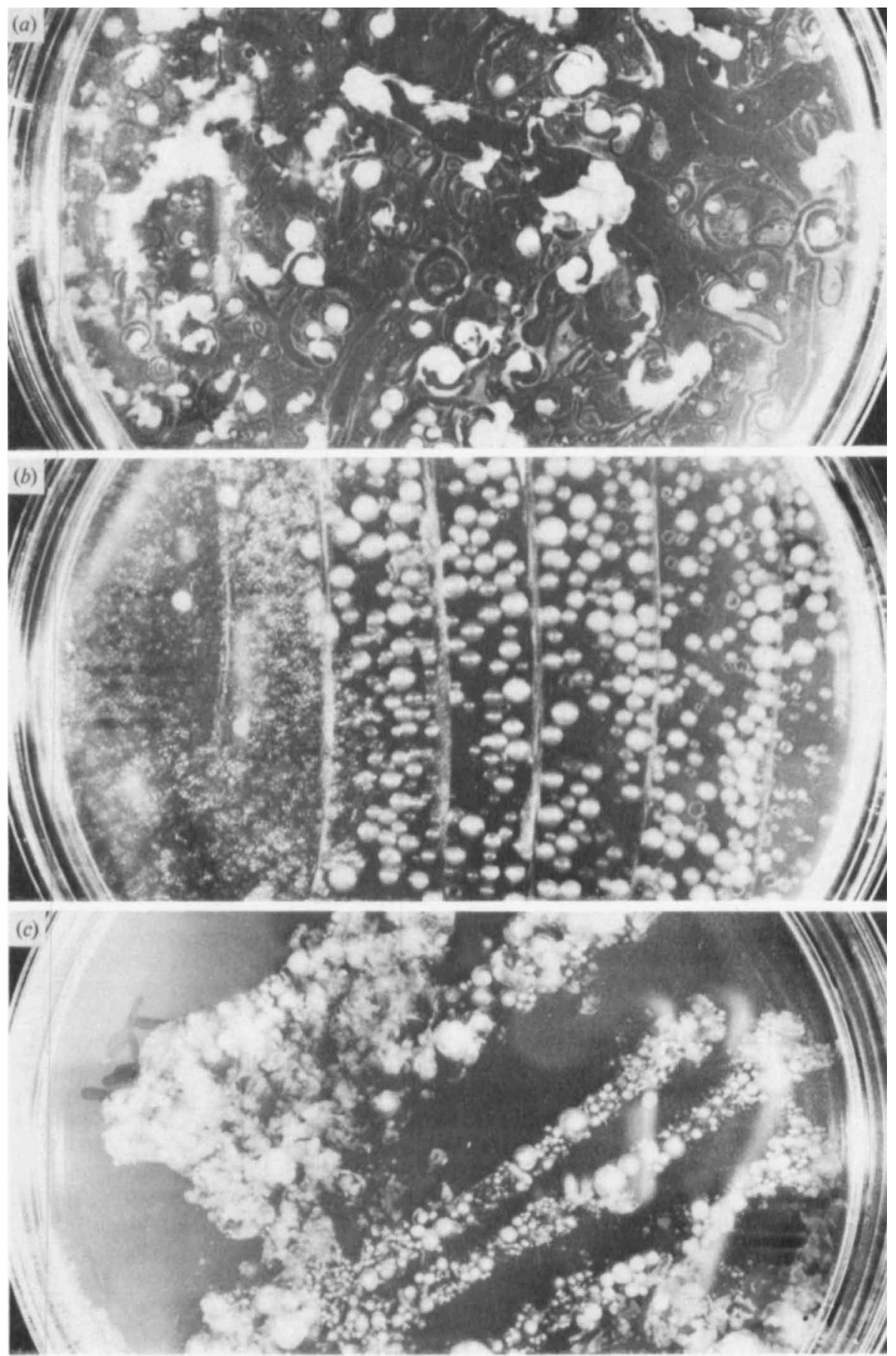

Fig. 2. Colonial morphologies/growth habits of isolate ISS101 and Vitreoscilla stercoraria. Isolate ISS 101 on TSA incubated at $(a) 10^{\circ} \mathrm{C},(b) 20^{\circ} \mathrm{C}$, and (c) $\mathrm{V}$. stercoraria on TSA incubated at $20^{\circ} \mathrm{C}$. 

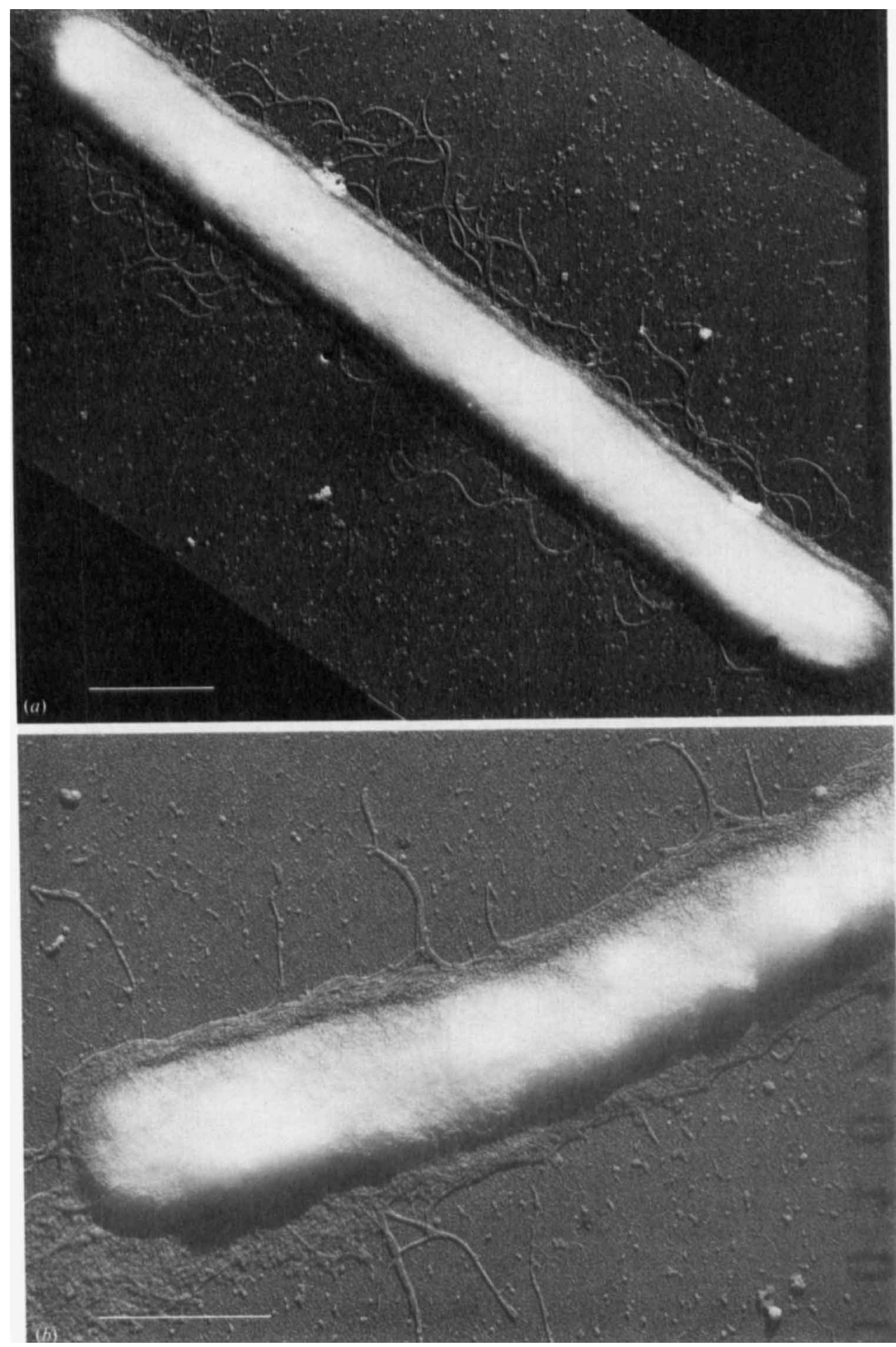

Fig. 3. Transmission electron micrographs of unfixed cells of isolate $1 \mathrm{SS} 10 \mathrm{l}$ showing (a) fibrils associated with the cell and (b) fibrillar material sloughing off a capsule-like covering of the cell. Bars, $1 \mu \mathrm{m}$. 
Table 2. Physiological characters of isolate ISSI0I and the two Vitreoscilla strains

\section{Physiological character}

Relation to oxygen

Temperature response (test-tube cultures): growth at $4{ }^{\circ} \mathrm{C}$

growth at $30^{\circ} \mathrm{C}$

survival at $4^{\circ} \mathrm{C}$ for $8 \mathrm{~d}$

Optimum temperature $\left({ }^{\circ} \mathrm{C}\right)$

Hydrolysis of:

casein

gelatin

starch

Growth on amino acids plus vitamins only

Utilization of other organic compounds

Enzymes:

catalase

oxidase

Oxidation of sulphide

- See utilization tests.

\author{
Isolate ISS10]
}

Strict aerobe

+
-
+
20

$-$

$+$

$+$

$-\bullet$

$+$

$+$

$-$

† Mayfield \& Kester (1972).
Vitreoscilla sp. strain 390

V. stercoraria

Strict aerobe

Strict aerobe

-
+
-
$25-30$

$-$

$+$

25-30

-

$-$

$-$

$+$

$-1$

$+$

$-$

‡N. Not tested.

movements which did not seem to be due to Brownian motion. Occasionally, cells $10-20 \mu \mathrm{m}$ long were seen to rotate slowly through $360^{\circ}$, with one end appearing to be attached to the glass. Very rarely, gliding filaments were observed. Filaments of $V$. stercoraria were never seen to glide in wet mounts. However, when in groups they waved about jerkily, bending at cell junctions. Vitreoscilla strain 390 showed similar movements, though not so vigorous. Media low in organic nutrients have been used to encourage gliding motility, but when plated onto NA with the nutrients at one-tenth the normal strength, strain 390 did not spread.

No sheaths or capsules were observed in any of the strains. Heat-fixed smears stained with carbol fuchsin showed the presence of stained material associated with, and between cells. Cell masses grown on agar media were sticky, suggesting that the organisms produced slime or mucilage. Electron micrographs of unfixed cells and filaments of ISS101 showed many to be covered with fibrillar material which often appeared as a capsule-like layer around the cells (Fig. 3 ), with the fibrils appearing to be peeling off from the structure. Some cells had very few fibrils, and cells fixed with glutaraldehyde $(3 \%, w / v)$ showed no sign of such material. None of the strains produced spores, nor were flagella observed. All three strains were Gram-negative. If safranin was used as counter stain, the two Vitreoscilla strains showed a poorly stained region at the centre of the their cells, whereas isolate ISS101 stained evenly. Isolate ISS101 and strain 390 contained one particle of Sudan Black-stained material per cell, but $V$. stercoraria contained none. Isolate ISS101 was poly- $\beta$-hydroxybutyrate (PHB) negative when tested by the method of Oste \& Holt (1982). Isolate ISSI0I was volutin negative, $V$. stercoraria was positive (one particle per cell), and strain 390 was positive, though not all cells in the smears had stained particles.

The physiological characteristics of the strains are summarized in Table 2. All were strict aerobes, growing well at the medium surface in shake cultures, with some growth to $2 \mathrm{~mm}$ depth. Isolate 1 SS 101 grew to a slightly greater depth $(3-4 \mathrm{~mm})$. In tubes with an agar plug, 1SS101 showed very slight growth at the surface of the semi-solid agar, but the other two strains did not. It is possible that 1SS101 may be able to grow at lower oxygen concentrations than the Vitreoscilla strains. Qualitative assessment of the growth of isolate 1SS101 suggested that it was more tolerant of low temperatures, and more sensitive to higher temperatures than the Vitreoscilla strains. This was confirmed by the temperature response curves of the three strains; isolate ISS101 had an optimum temperature in the region of $20^{\circ} \mathrm{C}$, and responded better to low temperatures than the other strains which had optimum temperatures around $25-30^{\circ} \mathrm{C}$.

None of the strains produced zones of clearing on media containing casein or starch. Only isolate $1 \mathrm{SS} 101$ gave a narrow clear zone (1-2 mm wide) on TSA plus gelatin. All three strains 
Table 3. Spectral data for cytochromes from various bacterial sources

\begin{tabular}{|c|c|c|c|}
\hline \multirow[b]{2}{*}{ Cytochrome/source } & \multicolumn{3}{|c|}{$\begin{array}{l}\text { Wavelengths of major peaks in reduce } \\
\text { room temperature spectra }(\mathrm{nm})\end{array}$} \\
\hline & Alpha & Beta & Soret \\
\hline Isolate $|S S 10|^{*}$ & 552 & 522 & 417 \\
\hline V. stercoraria" & 559 & - & - \\
\hline Vitreoscilla sp. strain $390^{*}$ & $558 \cdot 5$ & - & - \\
\hline Vitreoscilla sp. $\dagger$ & 560 & - & 427 \\
\hline Cytochrome $c$, various sources $\ddagger$ & 550 & 521 & 415 \\
\hline Cytochrome $c_{4}$, Azotobaciert & 551 & 522 & 416 \\
\hline Cytochrome $b_{1}$, bacteria $\ddagger$ & 560 & 530 & 426 \\
\hline $\begin{array}{l}\text { - Not deierm } \\
\text { - Experimental } \\
\text { † Published dat } \\
\text { † Published dat }\end{array}$ & $\begin{array}{l}\text { ebster \& } \mathrm{H} \\
\text { eilands (195 }\end{array}$ & 96 & \\
\hline
\end{tabular}

grew on a medium which contained purified amino acids as the only substrates. Isolate 1SS101, like $V$. stercoraria (Mayfield \& Kester, 1972) failed to grow on any of a range of common substrates (see below). All strains were catalase positive, isolate ISS101 was oxidase positive, but the two Vitreoscilla strains were oxidase negative. None of the strains deposited intracellular sulphur globules in the presence of sulphide, either in wet mounts or in broth cultures.

When tested by the API 20B system the three strains gave mainly negative results. Isolate ISS10I was urease and oxidase positive, the two Vitreoscilla strains were urease and oxidase negative. All three strains were catalase positive. The lack of response to the other tests can be attributed to lack of growth due to the absence of amino acids in the test medium. When tested by API ZYM, the Vitreoscilla strains were virtually identical in their responses. They both gave a strong reaction for esterase lipase (isolate ISSI0I did not), and they were negative for chymotrypsin whereas isolate $1 \mathrm{SS} 101$ gave a strong reaction. All three strains were positive for phosphoamidase, and negative for all the sugar metabolism enzymes. This agrees with previous observations of the nutritional indifference of these organisms to carbohydrates.

The oxidase test is commonly used to test for the presence of cytochrome $c$ in the respiratory chain. The work of Webster \& Hackett $(1966 a, b)$ has shown that Vitreoscilla strains possess $b$ type cytochromes as major components of their respiratory chain, and lack c-type cytochromes. The Vitreoscilla strains were oxidase negative, whereas isolate $1 \mathrm{SS} 101$ was oxidase positive. The cytochrome spectra were determined to further compare the respiratory chain compositions of the three strains. The absolute spectra for isolate 1 SS101 showed a Soret peak at $409 \mathrm{~nm}$ in the oxidized spectrum, which increased and shifted to about $417 \mathrm{~nm}$ when reduced. The absolute reduced spectrum also showed the characteristic cytochrome beta and alpha peaks at approximately $520 \mathrm{~nm}$ and $550 \mathrm{~nm}$, respectively, indicating the presence of $c$-type cytochromes. In reduced minus oxidized difference spectra of the alpha/beta bands of the three strains, the two Vitreoscilla strains both had alpha peaks at about $559 \mathrm{~nm}$, characteristic of b-type cytochromes, and isolate $1 S S 101$ had an alpha peak at $552 \mathrm{~nm}$ and a beta peak at $522 \mathrm{~nm}$, characteristic of $c$-type cytochromes. In isolate 1SS101, small shoulders in the alpha and beta peaks (at about $565 \mathrm{~nm}$ and $530 \mathrm{~nm}$, respectively) indicated the presence of lesser amounts of $b$ type cytochromes. The spectral properties of the cytochromes of the three strains are summarized in Table 3, together with published data for various cytochromes for comparison.

Analyses for isoprenoid quinones showed the major isoprenolog of Vitreoscilla stercoraria to be ubiquinone (Q-8), and of isolate 1 SS101, menaquinone (MK-7). The results of the mol $\% \mathrm{G}+\mathrm{C}$ determinations are given in Table 4. The values for the two Vitreoscilla strains were almost identical, but that for ISS101 was $6 \%$ lower.

\section{Utilization of carbon sources}

Isolate ISS101 grew well on TSB, following a normal growth curve, with a maximum growth rate equivalent to a generation time of $6.6 \mathrm{~h}$. It also grew with Casamino acids or the complete amino acid mixture, plus vitamins. In the absence of vitamins there was no growth. 
Table 4. DNA base ratios of isolate ISSIOI and the two Vitreoscilla strains

\begin{tabular}{|c|c|c|}
\hline Organism & $\begin{array}{c}\text { DNA melting } \\
\text { temperature. } T_{m} \\
\left({ }^{\circ} \mathrm{C}\right)^{*}\end{array}$ & $\begin{array}{l}\text { DNA base ratio } \\
(\mathrm{mol} \% \mathrm{G}+\mathrm{C})+\end{array}$ \\
\hline $\begin{array}{l}\text { Isolate ISSI01 } \\
\text { Vitreoscilla stercoraria } \\
\text { Vitreoscilla sp. strain } 390\end{array}$ & $\begin{array}{c}87 \cdot 45 \\
90 \cdot 0 \\
89 \cdot 55\end{array}$ & $\begin{array}{c}44 \cdot 3( \pm 0 \cdot 1) \\
50 \cdot 5 \\
49 \cdot 4( \pm 0 \cdot 1)\end{array}$ \\
\hline
\end{tabular}

None of the organic compounds tested supported growth of strain ISS101 in the absence of amino acids. There was no growth on BSA. In medium containing urea, the $\mathrm{pH}$ of the culture rose to over 9 after $12 \mathrm{~h}$ incubation, indicating an active urease. The potential carbon sources were also tested in the presence of amino acids at both substrate and growth factor level. Molar growth yields were calculated in terms of yield per mole of carbon $\left(Y_{c}\right)$ of amino acids, added substrate, and amino acid plus substrate (enabling comparison of mixtures of substrates), and the more conventional $Y_{3}$ (yield per mole of substrate). Many of the compounds tested were inhibitory, causing decreased yields, or in some cases, preventing any growth. No changes in pH which might account for these effects were detected. The only compounds which produced significantly enhanced yields were acetate, lactate, butyrate and glycerol, at $2 \mathrm{mg}$ atom carbon $1^{-1}$ with amino acids at $36.5 \mathrm{mg}$ atom carbon $\mathrm{I}^{-1}$. The $Y_{\mathrm{s}}$ values for these compounds $(17 \cdot 1,17.9$, 30.8 and $12.8 \mathrm{~g} \mathrm{~mol}^{-1}$, respectively) were of the same order as, but lower than, published values for a variety of other organisms (see Payne, 1970). In all cases, stimulation of growth decreased at higher substrate concentrations and lower amino acid concentrations. This was particularly so with butyrate.

Isolate ISS101 grew well on the complete amino acid mixture as sole carbon and energy source. The relationship between yield and amino acid concentration was linear over the range 20-70 mg atom carbon $^{-1}$, but was not linear at very low concentrations. This was probably due to growth limitation by certain required amino acids. No single amino acid alone supported the growth of isolate $1 \mathrm{SS} 101$, neither did any of the mixtures of amino acids from single families. Mixtures of amino acid families, omitting each family in turn, were used to determine whether any one family was essential for the growth of isolate ISS101. The results indicated that histidine was inhibitory, and that no single family (or single amino acid) was essential for growth. The aromatic family was also slightly inhibitory. Omission of the glutamate or aspartate families reduced the growth response, but not to the same extent as the omission of the serine or pyruvate families. However, the maximum growth rates and final yields were not greatly different. For further investigation of amino acid requirements, pairs of families were omitted. Absence of the glutamate or aspartate families decreased the yield, and omission of the serine or pyruvate families often produced long lag phases. In the absence of both the aspartate and serine families there was no growth.

To determine which families of amino acids could support the growth of isolate 1SS101, media containing pairs and triplets of families were used. The molar growth yields on pairs of families are given in Table 5. The only combinations which supported growth were the glutamate family plus the aspartate or serine families, and the aspartate family plus the pyruvate, serine or aromatic families. Best growth was obtained with the aspartate plus pyruvate families. The aspartate plus serine families gave a similar yield and growth rate, but with a much longer lag. After the aspartate plus pyruvate families, the next best growth was with the glutamate plus serine families, with a similar lag, but slightly lower yield and growth rate. The glutamate plus aspartate families gave a reasonable yield, but after a fairly long lag, and with a low growth rate. There was very slow growth with the aspartate plus aromatic families after a long lag. The aspartate plus pyruvate families gave the highest growth rate, but the glutamate plus serine families gave the highest molar growth yield. When the aspartate family was present, the absence of the pyruvate family again produced long lags as seen in the double omission experiments. The requirement for the aspartate or serine families for growth with the glutamate 
Table 5. Growth data of isolate ISSIOI on pairs and triplets of amino acid families

\section{Amino acid family added*}

All five (positive control)

Glutamate + aspartate

Glutamate + serine

Glutamate + pyruvate

Glutamate + aromatic

Aspartate + serine

Aspartate + pyruvate

Aspartate + aromatic

Serine + pyruvate

Serine + aromatic

Pyruvate + aromatic

Glutamate + aspartate + serine

Glutamate + aspartate + pyruvate

Glutamate + aspartate + aromatic

Glutamate + serine + pyruvate

Glutamate + serine + aromatic

Glutamate + pyruvate + aromatic

Aspartate + serine + pyruvate

Aspartate + serine + aromatic

Aspartate + pyruvate + aromatic

Serine + pyruvate + aromatic

$\begin{array}{ccc}\begin{array}{c}\text { Lag phase } \\ \text { (h) }\end{array} & \begin{array}{c}\text { Growth rate } \\ \text { constant, } \mu \\ \left(h^{-1}\right)\end{array} & \begin{array}{c}\text { Molar growth } \\ \text { yield, } Y_{c} \\ \text { [g (mol carbon) })^{-1} \text { ] }\end{array} \\ <5 & 0.107 & 8.37 \\ 94 & 0.012 & 3.14 \\ 25 & 0.026 & 4.77 \\ - & \text { No growth } & 0.00 \\ - & \text { No growth } & 0.00 \\ 115 & 0.035 & 4.00 \\ 27 & 0.041 & 4.21 \\ 160 & 0.007 & 1.46 \\ - & \text { No growth } & 0.00 \\ - & \text { No growth } & 0.00 \\ - & \text { No growth } & 0.00 \\ 175 & 0.055 & 5.79 \\ <5 & 0.024 & 5.46 \\ 102 & 0.022 & 2.43 \\ 22 & 0.055 & 7.23 \\ 42 & 0.028 & 4.04 \\ - & \text { No growth } & 0.00 \\ 30 & 0.058 & 5.38 \\ 80 & 0.041 & 3.38 \\ 19 & 0.032 & 3.74 \\ - & \text { No growth } & 0.00 \\ & & \end{array}$

- Each amino acid was added at a concentration equivalent to $2 \mathrm{mg}$ atom carbon $1^{-1}$. The control was the complete amino acid mixture.

family (previously indicated by the double omission experiments), was again demonstrated. The molar growth yields of isolate $1 S S 101$ on triplets of amino acid families are also given in Table 5 . The highest molar growth yield was obtained with the glutamate plus serine plus pyruvate families. A similar growth rate, but with a lower $Y_{c}$ was obtained with the aspartate plus glutamate plus serine families, and the lag was much longer. The highest growth rate was obtained with the aspartate plus pyruvate plus serine families, though there was a short lag and the yield was slightly lower than in the above cases. The shortest lag was with the glutamate plus aspartate plus pyruvate families, with a similar yield, but only $50 \%$ of the growth rate of the combinations discussed above.

Auxanography was used to determine the individual amino acids required by isolate ISS101. Overlay plates were superior to spread plates in that they overcame the problem of the irregular spreading growth habit of isolate 1SS101. Neither of the methods gave sufficiently clear results to determine precisely the individual amino acids required. However, there was some evidence that: of the glutamate family, glutamate, glutamine and proline were stimulatory but arginine was not; of the aspartate family, aspartate, asparagine, methionine and threonine were stimulatory; of the serine family, serine and glycine were stimulatory; and of the pyruvate family, alanine and possibly leucine were stimulatory. There was no observable stimulation or inhibition of growth by acetate, pyruvate or lactate spotted onto plates of the complete amino acid mixture.

\section{DISCUSSION}

\section{Characterization}

Isolate ISS101 has been characterized as a Gram-negative, non-pigmented, gliding, multicellular filamentous bacterium. As such it is differentiated from the unicellular, carotenoid-containing Flexibacteriaceae, and the multicellular carotenoid-containing Herpetosiphon. It did not oxidize sulphide and is thus differentiated from Beggiatoa and Thioploca. Its 
gliding motility and lack of a sheath differentiates the organism from the genera Haliscomenobacter, Sphaerotilus and Leptothrix. It was very different from Leucothrix spp. which are larger, solely marine organisms (but see Poffé et al., 1979), and reproduce via gonidia. Skuja (1956) described colourless, multicellular, gliding filaments of the genus Achroonema. Organisms resembling Achroonema spp. are often observed in Blelham Tarn sediment (Godinho-Orlandi \& Jones, $1981 b$ ), and differ in appearance from isolate 1SS101, being larger with characteristically granular cytoplasm. No Achroonema spp. have been isolated, so that further comparison is not possible.

In terms of morphological characteristics, isolate 1 SS101 resembled members of the genus Vitreoscilla. The characteristic growth habit on solid media and the lack of flagella indicated that the organism was a true gliding bacterium. Electron micrographs and other observations indicated that the cells were surrounded by a slime layer. Most gliding bacteria produce slime, which has been suggested to have a role in gliding motility (Burchard, 1981). The fibrillar nature of slime has been reported in several gliding bacteria, for example Herpetosiphon (Reichenbach \& Golecki, 1975). The specialization of the organism in the utilization of amino acids as sole carbon and energy sources resembled that of $V$. stercoraria (Mayfield \& Kester, 1972, 1975). The better response of isolate ISSI01 to lower temperatures may reflect its origin in aquatic sediment; $V$. stercoraria and strain 390 were both isolated from dung. Comparative characterization tests showed that in terms of cytochrome composition, isoprenoid quinones, DNA base ratios, and sensitivity to actinomycin D, isolate $1 S S 101$ differs significantly from the Vitreoscilla strains. The cytochrome and isoprenoid quinone compositions of bacterial respiratory chains are of increasing importance in bacterial taxonomy (Jones, 1980; Collins \& Jones, 1981), with major differences usually observed at generic or family level. On the basis of the observed differences, isolate 1SS101 does not belong in the same family as Vitreoscilla. Possession of menaquinone, unusual in Gram-negative aerobes, indicated affinity with the Flexibacteriaceae, which share this peculiarity (Collins \& Jones, 1981). The marked sensitivity of isolate ISS101 to actinomycin D also indicated a close relationship to the Flexibacteriaceae, which appear to be characterized by sensitivity to this agent (Dworkin, 1969).

Isolate ISS101 thus appears to be related to members of the Flexibacteriaceae. However, as it lacks pigmentation and actively flexing filaments, it does not resemble any described taxon of this family. On the basis of differences from Vitreoscilla strains, and from the Flexibacteriaceae, it is proposed that isolate ISS101 be placed in a new genus, Filibacter gen. nov., and it is named as the type strain of the type species, Filibacter limicola sp. nov. A culture of this strain has been deposited in the National Collection of Industrial Bacteria (NCIB no. 11923). To further compare the genus Filibacter with the Flexibacteriaceae it would be desirable to have data on fatty acid profiles and genetic homology. Also, analysis of isolate 1SS101 for capnoids would be useful. These unusual sulphonolipids have been reported to occur only in members of the Flexibacteriaceae and closely related organisms (Godchaux \& Leadbetter, 1983).

It is suggested that the definition of the genus Vitreoscilla be amended to include the characteristic cytochrome composition: oxidase negative with $b$-type cytochromes as major respiratory chain components.

\section{Physiology}

Isolate $1 \mathrm{SS} 101$ has been shown to be a strict aerobe, with a temperature optimum of $20^{\circ} \mathrm{C}$. It grew well on peptone-containing media at $\mathrm{pH} \mathrm{7.4,} \mathrm{and} \mathrm{had} \mathrm{a} \mathrm{requirement} \mathrm{for} \mathrm{vitamins.}$

None of the organic compounds tested could serve as sole carbon and energy source for isolate 1S\$101. The list of compounds tested was limited, but included all those most commonly found in lake sediments as major substrates of the bacterial flora. Also, most are intermediates in the main metabolic pathways. The organism, growing on amino acids, was able to produce more cell material in the presence of acetate, lactate, butyrate, or glycerol. However, the overall low values of $Y_{s}$, particularly at higher concentrations, indicated that any carbon/energy input from the substrates tested was of only minor importance.

Isolate 1SS101 grew well on a defined mixture of purified amino acids as sole carbon and energy source, and had a complex requirement for amino acids at substrate level. Histidine was 
inhibitory (possibly due to inhibition of glutamine synthetase), and the aromatic family was also inhibitory in most, but not all, cases. No single amino acid was essential for growth, but all were required for maximum growth. The failure of isolate 1SS101 to grow in the absence of both the aspartate and serine families showed that one or both of these was required for the utilization of the other components (glutamate, pyruvate and aromatic families). The long lags followed by growth at normal rates in the absence of the serine or pyruvate families suggested that these amino acids were required for growth, but when absent from the medium could be synthesized by inducible enzyme systems. For example, it was possible that isolate $1 \mathrm{SS} 101$ possessed the enzyme L-aspartate 4-decarboxylase (EC 4. 1 . 1 . 12) which converts L-aspartate to L-alanine, and that this was induced in the absence of L-alanine (pyruvate family).

From the results of all the amino acid experiments, the following conclusions can be drawn: (1) the glutamate and aspartate families were the major carbon sources; (2) utilization of the glutamate family, $(a)$ required the presence of the serine family, $(b)$ for maximum growth also required the pyruvate family and $(c)$ was inhibited by the presence of the aspartate family (possibly catabolite repression); (3) utilization of the aspartate family, (a) required the presence of the pyruvate family, $(b)$ in the absence of the pyruvate family required the necessary amino acid(s) to be synthesized by an inducible enzyme, and (c) required the presence of the serine family for maximum growth rate, and the glutamate family for maximum growth yield.

The nutrition of Filibacter limicola strain 1 SS101 with respect to amino acids as substrates is thus very similar to that of another filamentous gliding bacterium, Vitreoscilla stercoraria. Mayfield \& Kester $(1972,1975)$ reported that this organism required amino acids from more than one family at substrate level. As with strain 1SS101, the glutamate and aspartate families were the major carbon sources, but there were some differences. For example, $V$. stercoraria had a requirement for $L$-arginine as growth factor, and also required the aromatic family. The serine family was also important, but the pyruvate family was not. The serine family was required for maximum growth on the glutamate family, as with strain 1SS101. Results for growth on the aspartate plus aromatic plus pyruvate families were not given and therefore it is not known whether the pyruvate family was required for growth on aspartate. These requirements for particular combinations of amino acids indicate that the biochemistry of their utilization by these organisms may be novel and worthy of further study. The interdependence of the glutamate and serine families, and the aspartate and pyruvate families, suggests that pairs of amino acids from different families may be involved in specific coupled reactions. These may be transaminase reactions, or coupled oxidation-reduction reactions as in the Stickland reaction in anaerobes. The similarity of nutrition of strain $1 \mathrm{SS} 101$ and $V$. stercoraria is also interesting in the context of the important differences between them discussed above. Further strains will have to be isolated and studied in order to determine whether other Filibacter and Vitreoscilla spp. have the same mode of nutrition.

Ecologically, it is possible that Filibacter, Vitreoscilla and similar organisms specialize in the utilization of amino acids and may be important in the aerobic mineralization of amino acids in the lake sediments in which they occur. The specialized utilization of amino acids by these organisms is in contrast with the very versatile use of organic nitrogen compounds by planktonic unicellular heterotrophs (Sepers, 1981). A nutrient-rich environment such as sediment may support organisms with very limited substrate ranges, whereas in the water column a greater substrate versatility is one of the adaptations of planktonic bacteria for survival in a nutrientpoor environment (Poindexter, 1981). Amino acid concentrations in sediment may be of the order of $35 \mathrm{mg}$ glycine equivalents $1^{-1}$ (Simon \& Jones, 1982), as compared to concentrations in surface waters of the order of $35 \mu \mathrm{g} \mathrm{I}^{-1}$ (Sepers, 1981). Amino acid mineralization is the least studied part of the nitrogen cycle, and it would be of interest to investigate further the possible importance of filamentous bacteria in this process in lake sediment. The nutritional pattern of isolate 1 SS101 may be related to the relative abundance of individual amino acids in sediment. Jergensen et al. (1981) reported that glutamic acid and members of the serine and pyruvate families were the most abundant amino acids in the sediments they examined. The urease activity of strain ISS101 is interesting in the context of the importance of urea as a product of the decomposition of phytoplankton (Satoh, 1980). 
Description of Filibacter gen. nov.

Fi.li.bac'ter. L. n. filum a thread; M.L. masc. n. bacter masculine form of Gr. neut. n. bactrum a rod; M.L. masc. n. Filibacter thread rod.

Filaments composed of cylindrical cells, straight or curved. Cell junctions clearly marked by constriction. Filaments are flexible, but do not show active flexing, are not sheathed and do not branch. Motile by gliding, giving characteristic spreading growth and spiral colonies on solid media. Cell masses not pigmented. Resting stages not observed. Gram-negative. Strictly aerobic, catalase positive. Intracellular sulphur granules not formed in the presence of hydrogen sulphide.

Oxidase positive, major cytochrome component c-type. Major quinone isoprenolog is menaquinone (MK-7 in type strain).

The $\mathrm{G}+\mathrm{C}$ content of the type strain is $44 \mathrm{~mol} \%\left(T_{m}\right)$.

Type species: Filibacter limicola gen. et sp. nov.

\section{Description of Filibacter limicola sp. nov.}

li.mi'co.la L. n. limus mud; L. suff. verbal n. cola dweller; M.L. masc. n. limicola mud dweller.

Filaments $1.1 \mu \mathrm{m} \times 8-150 \mu \mathrm{m}$, cells $1.1 \mu \mathrm{m} \times 3-30 \mu \mathrm{m}$, rarely less than three diameters in length. Gliding motility about $5 \mu \mathrm{m} \mathrm{min}-1$. Grows well at $\mathrm{pH} 7 \cdot 4$. Optimum temperature $20^{\circ} \mathrm{C}$, slow growth at $4{ }^{\circ} \mathrm{C}$ and no growth above $26^{\circ} \mathrm{C}$. Gelatin hydrolysed, but casein and starch not hydrolysed. Sugars and organic acids not utilized, amino acids only are used as carbon and energy sources. Good growth on peptone-containing media.

Urease positive.

Isolated from lake sediment.

Type strain: 1SS101 (NCIB 11923).

We are grateful to Professor R. G. E. Murray (University of Ontario) for the culture of Vitreoscilla sp. strain 390 , Dr D. Jones (University of Leicester) for discussion of taxonomic aspects of the work, Dr D. Gibson and Mr I. Ogden (MAFF Torry Research Station, Aberdeen) for the $T_{m}$ determinations and Dr M. D. Collins (NIRD, Reading) for the isoprenoid quinone analyses. We also thank Dr J. C. Fry (UWIST, Cardiff) for helpful discussion during the course of this work, Dr A. D. Pickering for advice on electron microscopy, Mr T. I. Furnass for printing the photographs, and Miss Elisabeth $M$. Evans and Mrs Joyce Hawksford for typing the script. M. F. J. M. gratefully acknowledges the receipt of an NERC research studentship during the course of this work.

\section{REFERENCES}

BURCHARD, R. P. (1981). Gliding motility of prokaryotes: ultrastructure, physiology and genetics. Annual Review of Microbiology 35, 497-529.

Christensen, P. J. (1977). The history, biology, and taxonomy of the Cytophaga group. Canadian Journal of Microbiology 23, 1599-1653.

Collins, M. D. \& Jones, D. (1981). Distribution of isoprenoid quinone structural types in bacteria and their taxonomic implications. Microbiological Reviews 45, 316-354.

CONN, H. J. \& JENNison, M. W. (editors) (1957). Manual of Microbiological Methods. Society of American Bacteriologists Committe on Bacteriological Technique. New York: McGraw-Hill.

Costerton, J. W. F., Murray, R. G. E. \& Robinow, C. F. (1961). Observations on the motility and the structure of Vitreoscilla. Canadian Journal of Microbiology 7, 329-339.

DAWES, E. A. \& LARGE, P. J. (1973). Class II reactions: synthesis of small molecules. In Biochemistry of Bacterial Growth, pp. 202-205. Edited by J. Mande]stam \& K. McQuillen. Oxford, London, Edinburgh \& Melbourne: Blackwell Scientific Publications.
DOETSCH, R. N. (1981). Determinative methods of light microscopy. In Mamual of Methods for General Microbiology, pp. 21-33. Edited by P. Gerhardt, R. G. E. Murray, R. N. Costilow, E. W. Nester, W. A. Wood, N. R. Krieg \& G. B. Phillips. Washington: American Society for Microbiology.

DWORKIN, M. (1969). Sensitivity of gliding bacteria to actinomycin D. Joumal of Bacteriology $98,851-852$.

Gibson, D. M. \& OODEN, I. D. (1979). A rapid method for purifying bacterial deoxyribonucleic acid. Journal of Applied Bacieriology 46, 421-423.

GodChuUX, W. \& LEADbeTtER, E. R. (1983). Unusual sulfonolipids are characteristic of the Cytophagal Flexibacter group. Journal of Bacteriology 153, 12381246.

Godinho-OrLand, M. J. L. \& Jones, J. G. (1981a). Filamentous bacteria in sediments of lakes of differing degrees of enrichment. Journal of General Microbiology 123, 81-90.

Godinho-ORLANDi, M. J. L. \& Jones, J. G. (1981 b). The distribution of some genera of filamentous bacteria in littoral and profundal lake sediments. Journal of General Microbiology 123, 91-101. 
Güde, H., Strohl, W. R. \& LARKIN, J. M. (1981). Mixotrophic and heterotrophic growth of Beggiatoa albo in continuous culture. Archives of Microbiology 129, 357-360.

JONES, C. W. (1980). Cytochrome patterns in classification and identification including their relevance to the oxidase test. In Microbiological Classjfication and Identification, pp. 127-138. Society for Applied Bacteriology Symposium Series no. 8. Edited by $M$. Goodfellow \& R. G. Board. London: Academic Press.

JoNes, J. G. (1983). A note on the isolation and enumeration of bacteria which deposit and reduce ferric iron. Journal of Applied Bacteriology 54, 305310.

JGRGENSEN, B. B. (1977). Distribution of colourless sulphur bacteria (Beggiatoa spp.) in coastal marine sediments. Marine Biology 41, 19-28.

Jgrgensen, N. O. G., Lindroth, P. Mopper, K. (1981). Extraction and distribution of free amino acids and ammonium in sediment interstitial waters from the Limfjord, Denmark. Oceanologica Acta 4. 465-474.

Kovacs, N. (1956). Identification of Pseudomonas pyocyanea (aeruginosa) by the oxidase reaction. Nature, London 178, 703-704.

Leadbetter, E. R. \& Foster, J. W. (1958). Studies on some methane-utilising bacteria. Archiv für Mikrobiologie 30, 91-118.

LEIFsON, E. (1951). Staining, shape, and arrangement of bacterial flagella. Journal of Bacteriology 62, 377389.

LEWIN, R. A. (1969). A classification of Flexibacteria. Journal of General Microbiology 58, 189-206.

LEWIN, R. A. LOUNSBERY, D. M. (1969). Isolation, cultivation and characterization of Flexibacteria. Journal of General Microbiology S8, 145-170.

MAIDEN, M. F. J. (1983). The biology of filamentous bacteria in freshwater sediments. PhD. thesis, University of Wales Institute of Science and Technology.

MARMUR, J. (1961). A procedure for the isolation of deoxyribonucleic acid from microorganisms. Journal of Molecular Biology 3, 208-218.

MAYFIELD, C. I. INNiss, W. E. (1977). A rapid, simple method for staining bacterial flagella. Canadian Joumal of Microbiology 23, 1311-1313.

MAYFIELD, D. C. \& Kester, A. S. (1972). Physiological studies on Vitreoscilla stercoraria. Journal of Bacteriology 112, 1052-1056.

MAYFIELD, D. C. \& Kester, A. S. (1975). Nutrition of Vitreoscilla stercoraria. Canadian Journal of Microbiology 21, 1947-1951.

Minaes, C. G., Titus, J. A. \& Stroht, W. R. (1983). Plasmid DNA in colourless filamentous gliding bacteria. Archives of Microbiology 134, 38-44.

NEILANDS, J. B. (1958). Biological oxidations. Annual Review of Biochemistry 27, 455-488.

Nelson, D. C. \& Castenholz, R. W. (1981). Organic nutrition of Beggiatoa sp. Joumal of Bacteriology 147 , 236-247.

NoRris, J. R. SWaIN, H. (1971). Staining bacteria. Methods in Microbiology 5A, 105-134.

OHNSTAD, F. R. Jones, J. G. (1982). The Jenkin Surface-mud Sampler User Manual. Freshwater Biological Association Occasional Publication no. 15.
Oste, A. G. \& Hott, J. G. (1982). Nile Blue A as a fluorescent stain for poly- $\beta$-hydroxybutyrate. Applied and Environmental Microbiology 4, 238-241.

Patel, G. B., Khan, A. W. Roth, L. A. (1978). Optimum levels of sulphate and iron for the cultivation of pure cultures of methanogens in synthetic media. Journal of Applied Bacteriology 45 , 347-356.

PAYNe, W. J. (1970). Energy yields and growth of heterotrophs. Annual Review of Microbiology 24, 1752.

Pfennig, N., Widdel, F. \& Trü per, H. G. (1981). The dissimilatory sulphate-reducing bacteria. In The Prokaryotes, vol. 1, pp. 929-940. Edited by M. P. Starr, H. Stolp, H. G. Trüper, A. Balows \& H. G. Schlegel. Berlin, Heidelberg \& New York: SpringerVerlag.

Poffe, R., Vanderleyen, J. \& Verachtert, H. (1979). Characterisation of a Leucothrix-type bacterium causing bulking during petrochemical wastewater treatment. European Journal of Applied Microbiology and Biotechnology 8, 229-235.

PoINDEXTER, J. S. (1981). Oligotrophy. Fast and famine existence. Advances in Microbial Ecology 5 . 63-89.

Pringsheim, E. G. (1949). The relationship between bacteria and Myxophyceac. Bacteriological Reviews 13. 47-98.

Pringsheim, E. G. (1951). The Viteoscillaceae: a family of colourless, gliding, filamentous organisms. Journal of General Microbiology 5, 124-149.

Prinosheim, E. G. (1964). Heterotrophy and species concept in Beggiatoa. American Joumal of Botany 51 , 898-913.

Reichenbach, H. \& Dworkin, M. (1981). The order Cytophagales (with addenda on the genera Herpetosiphon, Saprospira, Flexithrix). In The Prokaryotes, vol. 1, pp. 357-379. Edited by M. P. Starr, H. Stolp, H. G. Trüper, A. Balows \& H. G. Schlegel. Berlin, Heidelberg \& New York: Springer-Verlag.

ReichenaACH, H. \& GoleckI, J. R. (1975). The fine structure of Herpetosiphon, and a note on the taxonomy of the genus. Archives of Microbiology 102. 281-291.

SATOH, Y. (1980). Production of urea by bacterial decomposition of organic matter including phytoplankton. Intermationale Revue der gesamten Hydrobiologie 65, 295-301.

Sepers, A. B. J. (1981). Diversity of ammonifying bacteria. Hydrobiologia 83, 343-350.

SimON, B. M. \& JONES, J. G. (1982). Gas chromatographic determination of total amino acids and proteins in sediments using the ninhydrin- $\mathrm{CO}_{2}$ reaction. Hydrobiologia 97, 81-96.

SxuJA, H. (1956). Taxonomische und biologische Studien aber das Phytoplankton schwedischer Binnengewalsser. Nova acta Regiae Societatis scientiarum upsaliensis 16, I-404.

Slisxhuis, H. Dennema, M. H. (1982). The physiology of Microthrix parvicella a filamentous bacterium isolated from activated sludge. In Bulking of Activated Sludge, pp. 75-85. Edited by B. Chambers E. J. Tomlinson. Chichester: Ellis Horwood.

SoRiano, S. (1973). Flexibacteria. Anmual Review of Microbiology 27, 155-170. 
Strohl, W. R., Cannon, D. W., Forbes, D. W., Shively, J. M., Hook, L. A. \& LARKIN, J. M. (1979). Assimilation of $\mathrm{CO}_{2}$ by Beggiatoa via a glyoxylatelinked reductive carboxylic acid cycle. Federotion Proceedings 38, 829.

Strohl. W. R., Cannon, G. C., Shively, J. M., GUde, H., HoOK, L. A., Lane, C. M. \& LaRkins, J. M. (1981). Heterotrophic carbon metabolism by Beggiatoa alba. Journal of Bacteriology 148, 572-583.

VeEn, W. L., VaN, Mulder, E. G. \& Deinema, M. H. (1978). The Sphaerotilus-Leptothrix group of bacteria. Microbiological Reviews 42, 329-356.

Weaster, D. A. \& Hackett, D. P. (1966a). The purification and properties of cytochrome o from Vitreoscilla. Joumal of Biological Chemistry 241. 3308-3315.

Weester, D. A. Hacket, D. P. (1966b). Respir- atory chain of colourless algac. II. Cyanophyta. Plant Physiology' 41, 599-605.

WIDDEL, F., KOHRING, G.-W. MAYER, F. (1983). Studies on dissimilatory sulphate-reducing bacteria that decompose fatty acids. III. Characterisation of the filamentous, gliding Desulfonema limicola gen. nov. sp. nov., and Desulfonema magnum sp. nov. Archives of Microbiology 134, 286-294.

WIESSNER, W. (1981). The family Beggiatoaceae. In The Prokaryotes, vol. I, pp. 380-389. Edited by M. P. Starr, H. Stolp, H. G. Trüper, A. Balows \& H. G. Schlegel. Berlin, Heidelberg \& New York : SpringerVerlag.

Wolin, E. A., Wolin, M. J. \& Wolpe, R. S. (1963). Formation of methane by bacterial extracts. Journal of Biological Chemistry 238, 2882-2886. 